\title{
Local Knowledge of Fishing Communities Pantai Labu Deli Serdang (Study about Pattern Treatment of Mother Pregnancy)
}

\author{
Desyanti Girsang, ${ }^{1}$ Ratih Baiduri'2, Pujiati ${ }^{3}$ \\ ${ }^{1}$ Departement of Anthropology \\ State University of Medan \\ Medan, Indonesia \\ ${ }^{2}$ Arabic Literature \\ University of Sumatera Utara \\ Medan, Indonesia \\ Email: desyantigirsanglehu@gmail.com
}

\begin{abstract}
This research analyzed of pattern treatment of mother pregnancy of fishing communities in Pantai Labu. This research uses descriptive approach qualitative with technique triangular as mean to study, depicting, elaborating, and analyzing thechange of pattern treatment of mother pregnancy of fishing communities Pantai Labu. Local knowledge of fishing communities Pantai Labu about pattern treatment of mother pregnancy one of traditional value from of fishing communities Pantai Labu which till now still found though have passed time from time to time. since obtained data indicate that has happened a change in treatment form, perceived by either through its context, treatment technique, and also elements in its treatment. Execution treatment context a period of pregnancy initially relate to copy process. If copy happened better and is fluent, is altogether seen by as an equity. There by can be said that by pattern existence treatment of mother pregnancy now remain its just protector. The happening of friction exactly make to survive its existence and represents one of the answers from given by challenge is modern approach as well as have shifted various life aspect, good of economic, cultural and social of-of fishing communities Pantai Labu especially.
\end{abstract}

Keywords-Local Knowledge; fishing communities; treatment pregnancy

\section{INTRODUCTION}

Health development in Indonesia covers the improvement of maternal and child health. Pregnancy and childbirth is a natural process that occurs in human life. In the process, humans have their own ways of preserving and maintaining the process of pregnancy and childbirth in accordance with customs, local knowledge, traditions, or customs within the community itself. Tradition or custom in the community continues to grow and important derivedbecause it has the benefits and benefits of cultural traditions. It is interesting to learn in order to see the ways of society according to the customs and habits of a community group. ${ }^{1}$

Community groups have certain ways of dealing with women who are pregnant and childbearing. Similarly, cultures have certain ways of responding to them and the deaths of babies and their mothers.Thus, pregnancy and birth are not only concerned with the aspect of physiology, but also the area of concern of social scientists, especially anthropology. According to Bower and Sargent (1990: 215) quoted by Meutia F.Swasono in the book Pregnancy, Birth, Mother, and Infant Care in the cultural context and patterns of culture about reproduction include beliefs and practices including

${ }^{1}$ Foster, George M. \& Barbara G.Anderson.Antropologikesehatan, diterjemahkanolehPriyantiP.Suryadama\&MeutiaF.Swasono.UI Press, Jakarta; 1986. beliefs and practices around menstruation, prohibitions, and suggestions during pregnancy. ${ }^{2}$ It is increasingly recognized that culture cannot be ignored in influencing the health status of fishing communities. Therefore research on the public health culture of fishermen in an effort to improve health status is very important to do.Logical consequences must be realized that the diversity of cultures that exist in Indonesia especially in the coastal areas requires a careful understanding of each region with the ethnicities in the region.A specific cultural understanding, by exploring local wisdom, can be used as a locally specific, locally specific health strategy.Objectively each particular community groups, especially in the fisherfolk communities have different health perceptions (concepts health pain).

This is largely determined by the culture of the people concerned.The culture of the fishing communities that characterize the pattern of life, and which has become a tradition of heredity, has great potential to affect health both from the negative and positive. Understanding the status of communitybased health is an effort to improve one's own health status, especially maternal and child health status.Maternal and child health issues can not be

${ }^{2}$ Swasono, Meutia F. (ed)

Kehamilankelahiran,perawatanibudanbayidalamkonteksbudaya. UI Press,Jakarta; 1998. 
separated from the social and cultural factors and the environment in the fishermen community where they are. Factors of belief and cultural knowledge such as conceptions about abstinence, causal relationships between food and healthy conditions-pain, habits, and knowledge of health, can have both positive and negative effects on health. It is a potential and a constraint that needs to be explored.Health problems related to socio-culture of fishermen communities become problems that require a more in-depth and specific study in each region with certain ethnicities. ${ }^{3}$

Culture can be a form of ideas, ideas, values, norms, rules, and so forth, which is often termed as customs. Another form of culture in the form of social system that is activity and action pattern from a human in society. The form of culture can also be a form of objects or things that can be seen, touched, and photographed the physical results of activities, deeds and works such as circumcision, pestle herbs, and so forth.

Health problems are often local health-related issues related to local socio-culture that need to be explored in order to find out the underlying problems so that they can be immediately improved or empowered for a culture that has a positive impact on health.Thus the richness of a good Indonesian culture can continue to be developed, conserved and utilized locally even when possible nationally. Understanding the culture of fisherman community is related to a health problem is very important to be considered as the determining factor to the success of health programs aimed at improving the quality of life of individuals and communities. The description can be used by health workers to know, learn, and understand what is applicable in the community. Based on the culture already monitored, health programs can be designed to improve maternal and child health status according to specific local issues. In this process, the cultural approach is one of the important and not neglected ways. From the above description, the research question is how the local knowledge of fishing communities of Pantai Labu Deli Serdang on health during pregnant women?

\section{METHODOLOGY}

The location chosen as the research area is in the village of Pantai Labu Deli Serdang Regency. This location was chosen because of the area that is still occupied by fishermen community active in fishery and marine activity. In this study using qualitative research approach as a technique to study, describe, describe, and analyze changes in treatment patterns of pregnant women fishing communities Pantai Labu.

${ }^{3}$ Wibowo.(1993), MakanandanPantanganUntukIbuHamil. [diunduh 25 Oktober 2017] Tersedia di http://www.midwife-no2 blokspot.com/ 2009/04/makanan-pantanganuntukibu hamil.html
Data collection techniques that have been done are using participant observation techniques, free and indepth interviews and literature study. Selection of informants with specific social situations, by themselves, needs to be done purposively (not randomly), ie on the basis of what is known about the variations that exist or the elements that exist. Selection of purposive informants as described above, also known as snowball sampling technique.

\section{RESULT AND DISCUSSION}

Perception of pregnancy owned by the community greatly determines the behavior of society towards pregnancy. Perception of pregnancy is formed based on beliefs and symbols owned by the community. The experience of pregnancy, in particular, is the source of symbols about fertility, the growth of the baby in the womb, and maternal and child health.Based on the results of the Limited Group Discussion and in-depth interviews, it was found that pregnancy is a special event in the family so the concern of family and community is high enough. This concern is manifested in the form of food taboos and behaviors that show a family's concern for the safety of the mother and her baby from things they deem harmful to pregnancy and childbirth.

"If her mother does not obey abstinence, the children who are born are often exposed to the disease, various illnesses, the child is born black, the body does not want big, the head and stomach are big" (in-depth interview with Mrs. Saima).

A view of abstinence and behavior during pregnancy

In the fishing communities of Pantai Labu, the types of food that are challenged during pregnancy and after childbirth are numerous. Although not adhered to by all pregnant women, because it no longer feels strong traditional influence to suppress the need for abstinence is obeyed. For those who still hold the belief in ancestral traditions recognizes the practice of eating taboos. They revealed a number of foodstuffs included in the taboo such as salted fish that they said could increase blood pressure, as well as dietary abstinence that feared could cause placenta or sticky tobacco (according to interviews with some mothers). In addition to food derived from seafood, there is also abstention to consume certain fruits. Fruits such as lime, pineapple, and durian are taboo. The mentioned lime may cause difficulty in labor, young pineapple and durian are considered to cause miscarriage.In addition to dietary restrictions, there are also some taboos in the form of behavior. The abstinence of such behavior is primarily related to the belief that the mother's behavior during the holiness will affect the safety and perfection of the baby being conceived. A pregnant woman should not wrap a towel around her neck because it will result in a baby 
born with a placenta wrapped, as one mother expressed:

"should not wrap a towel or cloth around the neck, then his child can sick umbilical cord" (interview with Saima).

According to information submitted by some informants, another taboo that is believed by the community in the study area is that the prospective parents of the baby should not be fishing, shooting birds, or harming animals. If this abstinence is violated, it is feared that the child conceived later will be hit by something bad when born. By believing and obeying the abstinence it affects the livelihood of both pregnant mothers and a husband whose eyes seek fish in the sea as fishermen after knowing his wife pregnant will rest the tools used to catch fish. They immediately seek other livelihoods as farmers, as farmhands working on other people's land or their own land. Some even work in the city as a builder or other work in a certain time until his wife gave birth.Another prohibition is not to sit in front of the door and step over a log or a broom that is crossing. Like an interview with a mother:

"Should not sit in front of the door because it will complicate the delivery process" (interview with the mother goddess).

Prohibition of other behaviors if sleep cannot use a pillow bolster because it will cause the baby was born with a large head, and should not sleep with a transverse position because it will cause the baby born breech. This is revealed through the statement of pregnant women supported the opinion of community leaders.

"I can not use a bolster, the child will have the same big head if sleeping can not breach the husband will be afraid of his breech child" (interview with community leaders).

In addition to abstinence actions that are bad for the baby and his mother, there are aspects of supernatural or supernatural danger. This is a common belief found in various ethnic groups in Indonesian beliefs about spirits. At the time of pregnancy, a woman is considered susceptible to disturbance coming from an unseen or demonic element. A woman who is pregnant is believed to have a distinctive aroma that will invite the spirits to come to the mother. The presence of these spirits is feared to disrupt so there are cultural ways to counter them. Fishing communities Pantai Labu has the belief there is a subtle spirit that interferes with pregnant women that can cause the mother to be mute and deaf. Such refined spirit is like a palasik, as one mother put it: "said the parents, pregnant people cannot walk sen / a because follow of Palasik can suck blood" (interview with the mother who was pregnant).

There are also taboos of behavior that must also be obeyed by the husband, implying also the view that child safety is not solely the responsibility of the wife but also her husband. In many cultures that embrace such beliefs, the usual abstinence is to kill or torture the animal that it considers to be resulting in the baby dies at birth or has a defect in his body like an animal that his parents had tortured.

"not to be fishing, because later his son is selected, should not cut the crab" (in-depth interview with Saima).

By health experts, health anthropology is viewed as a big business discipline that addresses the biological and socio-cultural aspects of human behavior, particularly about the interaction between the two throughout the history of human life that affects health and disease.The disease itself is determined by culture: it is because it is a social recognition that one can not perform its normal role normally. Man's way of life and lifestyle is a phenomenon that can be attributed to the emergence of various diseases, besides the results of various cultures can also cause disease. The public perception of the occurrence of disease differs from one region to another, because it depends on the existing culture and developing the community.

Similarly, about the perception of food for pregnant women. People everywhere in the world have categories of foods they know in their environment, which are based on a cultural conception.In the category of food, food ingredients categorized as food or non-food are also concerned understanding of its meaning culturally, how it is processed, how to consume it, when consuming or groups that consume it according to certain characteristics (age, gender, social status and other things). This category of food is not the same in various community groups. In other words, the same food can behave different values, roles, statuses and symbols in different groups of people with different cultures. Cultural knowledge of the various dangers and risks of the birth encouraged the abstinence of eating or doing certain actions by pregnant women. The existence of customs of food challenge and abstinence of certain behaviors does not always have health effects, although based on the purpose of hazard prevention.

\section{CONCLUSIONS}

The fishing communities of Pantai Labu still believe in the customs of eating and certain behaviors for pregnant and postpartum women. The cultural conception of abstinence is aimed at safeguarding the 
safety of mothers and infants, but the reasons put forward for abstinence. Man's way of life and lifestyle is a phenomenon that can be attributed to the emergence of various diseases, besides the results of various cultures can also cause disease. The public perception of the occurrence of disease differs from one region to another, because it depends on the existing culture and develops in the community. Similarly, about the perception of food for pregnant women. People everywhere in the world have categories of foods they know in their environment, which are based on a cultural conception.

\section{ACKNOWLEDGMENT}

Thank you to my parent for your support to me. I would like to thank all the fishermen who have received both researchers in searching information about the health of pregnant women, especially the people of Labu Beach, so the implementation of this research.

\section{REFERENCES}

Badan Penelitian dan Pengembangan Kesehatan, Riset Kesehatan dasar 2007, Depkes RI, Jakarta;2008.

Malonda, Benny Ferdy. Sosial budaya Gangguan emosi dan fisik paska salin masyarakat Pedesaan. Sumedang. Universitas SamRatulangi, Maluku; 2000.

Fauziah. C A. MitosTentangKehamilan, Aceh Research Training Nangroe Aceh Darusalam.2008.
Foster, George M. \& Barbara G.Anderson .Antropologi kesehatan, diterjemahkan oleh Priyanti P. Suryadama \& Meutia F. Swasono.UI Press, Jakarta; 1986.

Koentjraningrat., 1981, Kebudayaan Mentalitas dan Pembangunan, Bunga Rampai, Penerbit. PT Gramedia, Jakarta.

Kinseng, Rilus A. 2014. Konflik Nelayan. Jakarta: Yayasan Pustaka Obor Indonesia

Spradley, J, 1979.,DalamArtikelPengumpulan Dan Analisis Data Dalam Penelitian Etnografi.,

Bambang Hudayana, Jurnal Penelitian Agama, Media Penelitian dan Pengembangan IlmuIlmu Agama, Nomor 2, SeptemberDesember, Balai

Penelitian P3M IAIN SunanKalijaga Yogyakarta.

Swasono, Meutia F. (ed). Kehamilan kelahiran, perawatan ibudan bayidalamkonteksbudaya. UI Press,Jakarta; 1998.

Wibowo.(1993), Makanan dan Pantangan Untuk Ibu Hamil. [diunduh 25 Oktober 2017] Tersedia di

http://www.midwife-no2 blokspot.com/ 2009/04/makanan-pantanganuntukibu hamil.htm 
